\title{
Effects of Pesticides on Aquatic Organisms and Their Environment
}

\author{
Yasushi Hashimoto \\ Tokai Regional Fisheries Research Laboratory, \\ Komaki, Ueda 386, Japan
}

\section{INTRODUCTION}

In this country, pesticides are frequently applied near an aquatic environment including inland and coastal fishery nurseries, and the possibility always exists that they will contaminate the environment and cause hazards to the organisms inhabiting those areas. Therefore, special attention has been paid to the effects of pesticides on aquatic organisms and their environment, and a study of these effects began with the introduction of synthetic organocompound pesticides into this country in the second half of the 1940s. Since then, many scientific papers have been published and a mine of information has been accumulated. However, most of the information has not been conveyed to foreign researchers mainly due to the language barrier. In this paper will be outlined the current situation of the studies on this subject which have been conducted in Japan, primarily reviewing the literature published after 1970 .

\section{ACUTE TOXICITY}

The first purpose of this study was to prevent massive fish kills from occurring as a result of pesticides. Subsequently, extensive evaluation of the acute toxicity of individual pesticides has been made, using different methods or different kinds of organisms during the first twenty years period than are used now. A part of these data were summarized and tabulated by Hashimoto. ${ }^{1-4)}$

In 1965 "The standard method for the evaluation of acute toxicity of agricultural chemicals to fish" was established and issued as an ordinance by the Ministry of Agriculture, Forestry and Fisheries to give reproducible and comparable median tolerance limit (TLm) values of presiticides for carp. The entire text of the method is available in English with "A tentative method for the evaluation of acute toxicity of pesticides to daphnids. ${ }^{, 6}, 6$ )

Using these methods, 48-hour TLm values of all registered pesticides for carp, Cyprinus carpio, and 3-hour TLm values for Daphnia pulex and Moina macrocopa were determined by Hashimoto \& Nishiuchi, ${ }^{7)}$ Nishiuchi \& Hashimoto ${ }^{8,9)}$ and Nishiuchi. ${ }^{10)}$ The results revealed that rotenone and organochlorine insecticides, organomercurial, organotin, dimethyldithiocarbamate and phthalimide fungicides, dinitrophenol and PCP herbicides had high toxicity to carp, while organophosphorus and phenylcarbamate insecticides were extremely toxic to daphnids.

In addition to carp, the acute toxicity of pesticides to a wide range of aquatic animals was measured using standard methods, modified ones or improved flow-through systems. Goldfish, Carassius auratus, ${ }^{7)}$ tanago, Rhodeus moriokae, ${ }^{11)}$ dojo, Misgurnus anguillicaudatus $^{12-14)}$ and medaka, Oryzias latipes, ${ }^{7)}$ had sensitivity similar to carp. Ugui, Tribolodon hakuensis, ${ }^{15,16)}$ was more sensitive than carp although it belongs to the carp family. Rainbow trout, Salmo gairdneri, ${ }^{15-17)}$ and ayu, Plecoglossum altiverus, ${ }^{15,16)}$ which is taxonomically close to Salmonidae, were relatively more sensitive than carp, especially to organophosphorus insecticides.

Of marine fish, juvenile yellowtail, Seliola quinqueradiata, ${ }^{17-22)}$ agohaze, Chasmichthus 
dolichognathus dolichognatus, ${ }^{22,23)}$ mejina, Giella puctata, ${ }^{22,23)}$ bora, Mugil cephalus, ${ }^{24)}$ and madai, Pagurus major, ${ }^{24)}$ were found to be far more sensitive than carp, especially to organophosphorus insecticides.

Furthermore, Nishiuchi and his colleagues evaluated the toxicity of pesticides to aquatic animals other than fish. Larvae of the dragonfly, Orthetrum albistyrum speciosum, ${ }^{25)}$ and mayfly, Cloeon dipterum, ${ }^{26)}$ were found to have lower sensitivity than daphnids, but the correlation of their TLm values was comparatively high. The molluscean animals, red snail, Indoplanorbis exustus, ${ }^{27)}$ pond snail, Cipangopaludina chinensis malleata, ${ }^{27)}$ march snail, Semisulcospira libertina ${ }^{27)}$ and sakamakigai, Physa acuta, ${ }^{27)}$ had a generally low sensitivity to pesticides. Tadpoles of Bufo bufo japonica, ${ }^{28)}$ Rana brevipoda $a^{28)}$ and $R$. catesbeina ${ }^{28)}$ also had low sensitivity to the majority of pesticides.

Some field studies were also conducted. Matida et al. ${ }^{29-31)}$ and Yokote et al. ${ }^{32)}$ surveyed the effects of some forest use herbicides on aquatic organisms. No observable effects were produced by aerially applied sodium chlorate, or by a mixture of 2,4-D and 2,4,5,-T. Experiments in an artificial stream and the laboratory demonstrated that sodium chlorate, ammonium sulfamate, sodium tetrafluoropropionate, 2,4-D and 2,4,5-T had low toxicity to freshwater fish and insects. However, on exposure for 12 weeks to $0.02 \mathrm{ppm}$ of $2,4,5-\mathrm{T}$, rainbow trout showed retarded growth and pathological changes occurred in the liver, kidney, heart and skin. Takaku et al. ${ }^{33)}$ measured concentration of fenitrothion in paddy fields immediately following and 3 days after aerial application and found it to be 554 and $5 \mathrm{ppb}$, respectively. Population of a crustacean Moina sp., which had been dominant, decreased after the application but was recovered within 10 days. Plantonic algal growth was stimulated by the application.

\section{FACTORS INFLUENCING TOXICITY}

The factors influencing toxicity of pesticides or sensitivity of aquatic animals have been extensively studied. Nishiuchi ${ }^{34-36)}$ found that 99 kinds of 119 pesticides and 58 kinds of 89 pesticides tested were more toxic at higher temperatures to carp and daphnids, respec- tively. Hirose et al. ${ }^{23)}$ recognized that toxicity of diazinon, fenitrothion and phenthoate insecticides to mejina and agohaze increased at higher temperatures. According to Nishiuchi, ${ }^{37-39)}$ the majority of pesticides were less toxic to carp and medaka at higher $\mathrm{pH}$. Kobayashi \& Kishino ${ }^{40)}$ proved that the accumulation of pentachlorophenol (PCP) by goldfish decreased with an increase of the $\mathrm{pH}$ of PCP-media; consequently the PCP concentration in the fish body did not readily reach the lethal level at the high $\mathrm{pH}$, resulting in the reduction of the toxicity of PCP to fish.

Additionally, Nishiuchi ${ }^{41}$ ) showed that no apparent synergism or antagonism occurred between 6 pairs of organophosphorus and phenylcarbamate insecticides with carp. Hirayama \& Tamanoi $^{42)}$ investigated change of susceptibility with growth to fenitrothion and diazinon in kuruma prawn, Penaeus japonicas, and gazami crab, Portunus trituberculatus and found that the value of 24-hour TLm decreased with larval development from the nauplius to the post-larval stage. Hirose \& Kawakami ${ }^{43)}$ observed that embryonic development in medaka was not inhibited by DDT or phenthoate at concentrations of from $1 / 10$ to $1 / 100$ of 48 -hour TLm values for adults. Hashimoto \& Fukami ${ }^{44}$ proved that dietary pesticides are in general less toxic to carp than pesticides in bath exposure systems.

\section{OCCURRENCE OF DEFORMED AND ANEMIC FISH}

In the $1960 \mathrm{~s}$ and $1970 \mathrm{~s}$, distribution of deformed fish was reported from every part of this country, and the occurrence of body curvature in the yellowtail population in coastal fishery farms received special attention. Since it was reported that some organophosphorus insecticides could induce fractured vertebral columns and hemorrhaged areas around the columns in medaka, ${ }^{45)}$ motsugo, Pseudorasbora parva, ${ }^{46)}$ dojo and carp, the deformity in yellowtail was suspected to be caused by these pesticides and experimental evidence was provided by Baba et al. ${ }^{19-21)}$ However, no confirming evidence was presented that organophosphorus pesticides were the primary cause of the deformity in the fishery farms. Fractured vertebral column 
was also induced experimentally in agohaze ${ }^{22)}$ and medina ${ }^{22)}$ from organophosphorus insecticides. It was also revealed that some of carbamate insecticides, especially o-sec-butylphenyl methylcarbamate (BPMC) induced the deformity in yellowtail, ${ }^{21)}$ carp, ${ }^{47)}$ medaka $^{47)}$ and dojo, ${ }^{47)}$ and trifluralin herbicide did so in carp $^{47)}$ and medaka. ${ }^{47)}$

Since 1973, a series of massive kills of carp had been reported from the central and northeast parts of this country. Killed fish had been reared in carp production ponds into which irrigation water from paddies flowed, and they showed pronounced symptoms of anemia. After a great deal of effort, it was proved that herbicides containing molinate induced similar symptoms with a decrease of hematocryt value. ${ }^{48-50)}$ The anemia was characterized by a drastic decrease of $\mathrm{RBC}$ and $\mathrm{Hb}$ levels, and an increase in the number of immature erythrocytes; it was concluded to be due to loss of blood resulting from the alteration of the gill- capillary wall. ${ }^{51)}$ Furthermore, Ochiai \& Kubota $^{52)}$ proved that the hemmorhage in the anemic carp occurred mainly in the gill lamella and at the tip of gill filaments and was effectively prevented from occurring by giving advance doses of vitamin $K_{3}$ or $K_{4}$. Similar symptoms were also induced by the benthiocarb herbicide. ${ }^{53)}$

Suzuki et al. ${ }^{54)}$ detected residual molinate from the hematopancreas and kidney of the carp suspected to be killed by the herbicide. Death of carp was first observed after about 7 days exposure to $10 \mathrm{ppb}$ or higher concentrations of molinate and most frequently after 10-15 day exposure. Occurrence of carp with anemia was found to increase with an increase of molinate concentration. ${ }^{55}$ ) Residual molinate and benthiocarb were detected in the rivers soon after the herbicide began to be used in the surrounding paddies, peaked after 2-3 weeks reaching higher than $10 \mathrm{ppm}$ and rapidly decreased. The peaks in the carp production ponds appeared about 10 days later than the rivers. ${ }^{56)}$

\section{UPTAKE, MECHANISM AND METABOLISM}

Kobayashi et al. ${ }^{57,58)}$ showed that a shellfish, Tapes philippinarum, rapidly absorbs PCP from the solution, but that this is largely detoxicated by conjugation with sulfate to be eliminated. The physiological changes produced in carp from exposure to malathion, dichlorvos and trichlorfon were investigated by Sakaguchi. ${ }^{59)}$ Results showed that activity of serum transaminases (GOT and GPT) increased and that of Ch-E decreased. Serum glucose, triglyceride and total cholesterol contents were lowered, while protein content remained unchanged. Sakaguchi ${ }^{(0)}$ also observed the increased fat and decreased glycogen in liver as well as increased activity of serum GOT, GPT and LDH for rainbow trout exposed to $2 \mathrm{ppm}$ of trichlorfon. Miyauchi et $a l .{ }^{61,62)}$ studied the toxicology of nitrofen and chlornitrofen and found that their nitrosoderivatives induced the methemoglobin formation in white-spotted char, Salivelinus leucomaenis, erythrocytes as well as human erythrocytes. The char liver homogenate had the ability to metabolize $p$-aminophenyl ether to methemoglobin-forming metabolites, although it was very low in comparison with rat liver homogenate.

According to Takimoto \& Miyamoto, ${ }^{63)}$ fenitrothion was metabolized in rainbow trout to sumioxon, 3-methyl-4-nitrophenol and its glucuronide. Seguchi \& Asaka ${ }^{64)}$ showed that the major metabolite of diazinon in freshwater fish was 2-isopropyl-4-methyl-6-hydroxy-pyrimidine, and not diazoxon. Ohkawa et al. ${ }^{65)}$ revealed that metabolism of $S$-fenvalerate proceeded through hydroxylation at the phenoxy group, hydrolysis of the $\mathrm{CN}$ group and cleavage of the ester linkage in all of carp, snails, daphnids and algae.

Kobayashi and his group ${ }^{66-73)}$ studied the metabolism of chlorophenols in goldfish. PCP was concentrated up to 1,000 times after 120 hour exposure, but was rapidly excreted when the fish were transferred into clear water, showing a biological half-life of 10-20 hours. The excretion was performed mostly through the branchial, renal and biliary routes. As conjugates, pentachlorophenyl sulfate and pentachlorophenyl- $\beta$-glucuronide were isolated and identified. The sulfate conjugate was excreted into the surrounding water and urine of the fish, while the glucuronide conjugate went into the bile. The excreted amounts 
from the branchial, renal and bilary routes were approximately $52,24,22 \%$ of the total in fish exposed to $0.1 \mathrm{ppm}$ of PCP for 24 hours. The excretion from the body surface was negligibly small. They ${ }^{74}$ also examined the turnover of absorbed PCP in a shellfish, Tapes philippinarum. The results showed that PCP was rapidly absorbed from the media, distributed into the various tissues, especially the Bojanus' organ and liver, and quickly eliminated presumably from the Bojanus' organ. Takimoto \& Miyamoto ${ }^{63)}$ showed that fenitrothion was distributed in every tissue except brain and heart in rainbow trout after 24 hour exposure. Shimizu et al. ${ }^{75)}$ administered DDT and parathion to carp by bath exposure, food exposure, topical application and oral and anal injection. It was found that gall bladder concentrated the insecticides from these five treatments. The concentration of DDT and/or its metabolites in the brain was lower by food exposure than bath exposure. According to Miyauchi et al., ${ }^{76)}$ it was not easy for nitrofen and chlornitrofen to be metabolized in goldfish. These herbicides were accumulated in considerable amounts in the adipose tissue and the excretion was very slow.

\section{ENVIRONMENTAL CONTAMINATION}

DDT, BHC and cyclodiene insecticides, and organomercurial fungicides posed a serious food and environmental contamination problem especially during the 1970s. Use of these pesticides was prohibited or strictly limited before 1971, but the level of contamination could not be rapidly lowered. For example, Hori \& Nakaji ${ }^{77}$ observed that the concentration of total $\mathrm{BHC}$ in the rivers in Kumamoto Prefecture, where the insecticide had been heavily used, decreased during 1970-1973 but that no further decrease occurred during 19731975. According to Watanabe et al. ${ }^{78)}$ who pursued residue of $\mathrm{BHC}$ and DDT in the freshwater fish, isaza, Chaenogobius isaza, from 1966 to 1976, the concentration did not show much decrease even after 1971.

They also found that the concentration of chlornitrofen, which is still in use, in fish had been increasing annually. Yamagishi et al. ${ }^{79}$ ) also detected approximately $1 \mathrm{ppm}$ of chlornitrofen on a wet basis in the mussel, Mytilus edulus, collected from Tokyo Bay in 1977. In addition, the ${ }^{80)}$ established a determination method for residual nitrofen and chlornitrofen in fish and shellfish, and Yamagishi \& Akiyama $^{81)}$ determined chlornitrofen concentrations in the goby fish, Acanthogobius flavimanus, sea bass, Lateolabrax japonica, short-necked clam, Tapes philippinarum, and seawater. The concentration was highest in liver of the goby fish, and lowest in the seawater. Miyazaki et al ${ }^{82-84)}$ found that goby fish from Tokyo Bay contained oxychlordane, trans- and cischlordane, and trans- and cis-nonachlor, and oyster, Crassistrea gigas, contained polyhalogenated anisoles and phenol. In addition, Yamagishi et al. ${ }^{85)}$ detected chlordane residue in fish and shellfish from coastal areas near big cities other than Tokyo. The contamination of the oyster by polychlorinated anisoles and phenols, probably derived from $\mathrm{PCP},{ }^{84}$ ) and that of oikawa Zacco platypus by 1,3,6,8tetrachlorinated dibenzodioxine, an impurity of chlornitrofen and chlordane-related residue ${ }^{86}$ ) were also evidenced.

Persistence of pesticides, especially those aerially applied, has been extensively surveyed. Mikuriya \& Miyahara ${ }^{87-89)}$ monitored the residue levels of organophosphorus, carbamate and cartap insecticides, and benthiocarb, nitrofen, chlornitrofen and symetryne herbicides in creeks near paddy fields where these pesticides were applied, and found that the levels were largely dependent on the interval since application and the amount of pesticides used. Kato \& Maru, ${ }^{90}$ ) found a similar decline pattern for benthiocarb and molinate herbicides by ground application in river water. According to Kono et al. ${ }^{91)}$ the concentration of diazinon in paddy water was significantly higher than that in river water just after aerial application, but the former decreased rapidly with time to be lower than the latter after 7 days. Yamaya \& Mizuno $^{92)}$ observed that the concentration of fenitrothion and BPMC in paddy and drainage water had been higher than in river water until 7 days after the aerial application. The concentration in the river was highest in the upper part on the day of application, but in the lower part on the following days. Omae et al. ${ }^{93)}$ confirmed that fenitrothion fallout from aerial applica- 
tion was rapidly diluted in the river, but that it maintained a low concentration for a long time. Kodama \& Kuwatsuka ${ }^{94)}$ revealed that the persistence of organophosphorus insecticides in the water environment was affected mostly by water quality and light and partially by temperature, but not by suspended solids and vaporization. Nakaji \& Hori ${ }^{95)}$ pointed out that microorganisms played an important role in decomposition of organophosphorus pesticides in river water.

\section{MODEL ECOSYSTEM AND BIOLOGICAL CONCENTRATION}

In order to determine in advance, those pesticides having high persistence and possible biological concentration in the environment, such as DDT, some laboratory model ecosystems were developed. Kazano et al. ${ }^{96)}$ modified the system proposed by Metcalf et $a l .{ }^{97)}$ and found that the ecological magnification (EM) of 3,5-xylylmethylcarbamate (XMC) insecticide was relatively small in comparison with that of organochlorine insecticides. Employing the same system, Tomizawa \& Kaza$\mathrm{no}^{98)}$ showed that EM values of DDT, disulfoton, chlornitrofen, $\beta$ - and $\gamma$-isomers of $\mathrm{BHC}$ were large in guppies, Levistes reciculatus, and those of DDT and chlornitrofen in red snails were far larger than those of $\alpha$-isomer of BHC, pyridaphenthion, cartap, $S$-benzyl diisopropyl phosphorothiolate (IBP), edifenphos and PCP in both animals. Ohkawa et al $^{65}{ }^{65}$ modified an aquatic model ecosystem as described by Isensee $^{99)}$ and proved that bioaccumulation ratios for $(S)$-acid isomer of fenvalerate ranged from 69 to 117 in carp and were lower than in snails, Cipangopaludina japonica, Daphnia pulex and algae. Ishizuka et al. ${ }^{100)}$ devised a simple ecosystem containing only guppies and water as components, where pesticide concentration state of equilibrium between organisms and the aqueous phase is always kept. In this system, concentration factors of 2,4-D, barban, thiochlormethyl, chlormethoxynil and DDT were greater in this order in proportion to the partition coefficient between water and octanol as Metcalf et al. ${ }^{97)}$ and Chiou et al. ${ }^{101)}$ had pointed out. Kanazawa \& Tomizawa ${ }^{102)}$ exposed topmouth gudgeon (motsugo) to continuous flow water containing $20 \mathrm{ppb}$ of chlor- nitrofen and observed that the concentration in the fish body reached $21.3 \mathrm{ppm}$ after 15 days. With the same method, Kanazawa ${ }^{103)}$ evaluated bioconcentration ratios of diazinon in topmouth gudgeon, silver crucian carp, Cyprinus auratus, carp, guppy, crayfish, Procambarus clarkii, red snail and pond snail to be $152,36.6,65.1,17,3,4.9,17.0$ and 5.9 , respectively. In a continuous flow system, fenitrothion was found to be readily taken up by rainbow trout and motsugo with maximum bioconcentration of 200-250, but disappeared rapidly on transference of the fish to clean water. According to Seguchi \& Asaka, ${ }^{64)}$ the intake and excretion pattern of diazinon in carp, rainbow trout and dojo was similar to that of fenitrothion. However, Imanaka et al. ${ }^{104)}$ suggested that possibility that oxadiazon herbicide may have a strong persistence in crucian carp, Carassius cuvieri. Sugiura et al. ${ }^{105)}$ showed that an aquatic microcosm containing polypeptone, inorganic substances and microorganisms such as bacteria or algae in a conical beaker is a useful tool to evaluate toxic effects of chemicals on the natural ecosystems. Tsuge et al. ${ }^{106)}$ devised a closed type model ecosystem in order to trap volatile and gaseous metabolites and recovered 51.4 and $62.1 \%$ of the radioactivity from carbaryl and DDT, respectively. Kazano et al. ${ }^{107)}$ used the same closed system, revealing that $\mathrm{N}_{-} \mathrm{CH}_{3}-\left({ }^{14} \mathrm{C}\right)$ labelled XMC was degraded to produce ${ }^{14} \mathrm{CO}$ as the major compound among ${ }^{14} \mathrm{C}$-metabolites.

\section{REFERENCES}

1) Y. Hashimoto: Noyaku Seisan Gijutsu No. 8, 59 (1963)

2) Y. Hashimoto: Noyaku Seisan Gijutsu No. 10, 49 (1964)

3) Y. Hashimoto: Noyaku Seisan Gijutsu No. 17, 43 (1967)

4) Y. Hashimoto: Noyaku Seisan Gijutsu No. 18, 69 (1967)

5) Y. Hashimoto: Jpn. Pestic. Inf. No. 3, 15 (1970)

6) Y. Hashimoto: PANS 15, 325 (1969)

7) Y. Hashimoto \& Y. Nishiuchi: Aquiculture 15, 79 (1967)

8) Y. Nishiuchi \& Y. Hashimoto: Bochu-Kagaku 32, 55 (1967)

9) Y. Nishiuchi \& Y. Hashimoto: Aquiculture 16, 19 (1968) 
10) Y. Nishiuchi: Aquiculture 19, 69 (1971)

11) Y. Nishiuchi: Aquiculture 24, 146 (1977)

12) Y. Nishiuchi, K. Yoshida \& Y. Hashimoto: Aquiculture 18, 227 (1971)

13) Y. Nishiuchi: Aquiculture 19, 87 (1971)

14) Y. Nishiuchi: Aquiculture 19, 93 (1971)

15) K. Hori, H. Ohtsuka, K. Satsumi, S. Kurosawa \& M. Motegi: Bull. Gunma Pref. Fish. Exp. Stn. No. 20, 83 (1977)

16) K. Hori, H. Ohtsuka, S. Kurosawa \& M. Motegi: Bull. Gunma Pref. Fish. Exp. Stn. No. 57, 79 (1978)

17) M. Matsushima: Bull. Shizuoka Pref. Fuji Trout Cult. Lab. No. 2, 99 (1978)

18) M. Nara \& Y. Yamashita: Bull. Shizuoka Pref. Fish. Exp. Stn. No. 6, 45 (1973)

19) K. Baba, M. Nara, Y. Iwahashi, M. Matsushima \& T. Sasaki: Bull. Shizuoka Pref. Fish. Exp. Stn. No. 9. 43 (1975)

20) K. Baba, M. Nara, Y. Iwahashi, M. Matsushima \& T. Sasaki: Bull. Shizuoka Pref. Fish. Exp. Stn. No. 9, 82 (1975)

21) K. Baba, M. Nara, Y. Iwahashi, T. Sasaki \& H. Osuga: Bull. Shizuoka Pref. Fish. Exp. Stn. No. 11, 51 (1977)

22) K. Hirose \& M. Kitsukawa: Bull. Tokai Reg. Fish. Res. Lab. No. 84, 11 (1976)

23) K. Hirose, M. Yamazaki \& J. Ishikawa: Bull. Tokai Reg. Fish. Res. Lab. No. 98, 45 (1979)

24) Y. Igarashi, T. Ai \& Y. Harada; Bull. Shizuoka Pref. Fish. Exp. Stn. No. 15, 59 (1981)

25) Y. Nishiuchi \& K. Asano: Aquiculture 26, 26 (1978)

26) Y. Nishiuchi \& K. Asano: Aquiculture 27, 48 (1979)

27) Y. Nishiuchi \& K. Yoshida: Bull. Agric. Chem. Insp. Stn. No. 12, 86 (1972)

28) Y. Nishiuchi \& K. Yoshida: Noyaku Seisan Gijutsu No. 26, 59 (1971)

29) Y. Matida, Y. Furuta, H. Kumada, H. Tanaka, Y. Yokote \& S. Kimura: Bull. Freshwater Fish. Res. Lab. No. 25, 41 (1975)

30) Y. Matida, S. Kimura, H. Kumada \& M. Yokote: Bull. Freshwater Fish. Res. Lab. No. 25, 55 (1975)

31) Y. Matida, S. Kimura, H. Tanaka \& M. Yokote: Bull. Freshwater Fish. Res. Lab. No. 26, 79 (1976)

32) M. Yokote, S. Kimura, H. Kumada \& Y. Matida: Bull. Freshwater Fish. Res. Lab. No. 26, 85 (1976)

33) T. Takaku, M. Takahashi \& A. Otsuki: Jpn. J. Limnol. 40, 137 (1979)

34) Y. Nishiuchi: Aquiculture 24, 140 (1977)

35) Y. Nishiuchi: Aquiculture 19, 1 (1972)

36) Y. Nishiuchi: Aquiculture 19, 7 (1972)
37) Y. Nishiuchi: Aquiculture 25, 27 (1977)

38) Y. Nishiuchi: Aquiculture 25, 77 (1977)

39) Y. Nishiuchi: Aquiculture 25, 151 (1978)

40) K. Kobayashi \& T. Kishino: Bull. Jpn. Soc. Sci. Fish. 46, 167 (1980)

41) Y. Nishiuchi: Aquiculture 26, 144 (1978)

42) K. Hirayama \& S. Tamanoi: Bull. Jpn. Soc. Sci. Fish. 46, 117 (1980)

43) K. Hirose \& K. Kawakami: Bull. Tokai Reg. Fish. Res. Lab. No. 91, 9 (1977)

44) Y. Hashimoto \& J. Fukami: Bochu-Kagaku 34, 63 (1969)

45) Y. Matsue, T. Endo \& K. Tabata: Bull. Jpn. Soc. Sci. Fish. 23, 358 (1957)

46) Y. Hashimoto \& H. Sugahara: Jpn. J. Appl. Entomol. Zool. 5, 145 (1961)

47) Y. Nishiuchi: Aquiculture 19, 151 (1975)

48) S. Fukatsu: Oral Presentation at the Annual Meeting of Japanese Society of Scientific Fisheries, 1976

49) M. Aihara \& Y. Ito: Annual Report from Yamagata Pref. Freshwater Fish Cult. Lab., p. 111,1977

50) M. Aihara \& T. Oki: Annual Report from Yamagata Pref. Freshwater Fish Cult. Lab., p. 118,1977

51) H. Kawatsu: Bull. Jpn. Soc. Sci. Fish. 43, 905 (1977)

52) T. Ochiai \& S. Kubota: Bull. Fac. Fish. Mie Univ. No. 5, 129 (1978)

53) T. Ochiai \& S. Kubota: Bull. Fac. Fish. Mie Univ. No. 5, 155 (1978)

54) K. Suzuki, K. Otaki, T. Takahashi, M. Tsujimitsu \& T. Ono: Bull. Fukushima Inlandwater Fish. Exp. Stn. No. 1, 23 (1978)

55) K. Otaki, K. Suzuki \& T. Takakoshi: Bull. Fukushima Inlandwater Fish. Exp. Stn. No. 1, 30 (1978)

56) K. Suzuki, S. Nagasawa \& N. Nemoto: Bull. Fukushima Inlandwater Fish. Exp. Stn. No. 2, 33 (1979)

57) K. Kobayashi, H. Akitake \& T. Tomiyama: Bull. Jpn. Soc. Sci. Fish. 36, 96 (1970)

58) K. Kobayashi, H. Akitake \& T. Tomiyama: Bull. Jpn. Soc. Sci. Fish. 36, 106 (1970)

59) H. Sakaguchi: Bull. Jpn. Soc. Sci. Fish. 38, 555 (1972)

60) H. Sakaguchi: Bull. Hyogo Pref. Fish. Exp. Stn. No. 17, 69 (1979)

61) M. Miyauchi, M. Takagi \& T. Uematsu: Bull. Jpn. Soc. Sci. Fish. 45, 1563 (1979)

62) M. Miyauchi, M. Takagi \& T. Uematsu: Bull. Jpn. Soc. Sci. Fish. 45, 1569 (1979)

63) Y. Takimoto \& J. Miyamoto: J. Pesticide Sci. 1, 261 (1976)

64) K. Seguchi \& S. Asaka: Bull. Environ. Contam. 
Toxicol. 27, 244 (1981)

65) H. Ohkawa, R. Kikuchi \& J. Miyamoto: J. Pesticide Sci. 5, 11 (1980)

66) K. Kobayashi \& H. Akitake: Bull. Jpn. Soc. Sci. Fish. 41, 87 (1975)

67) K. Kobayashi \& H. Akitake: Bull. Jpn. Soc. Sci. Fish. 41, 93 (1975)

68) H. Akitake \& K. Kobayashi: Bull. Jpn. Soc. Sci. Fish. 41, 321 (1975)

69) K. Kobayashi \& H. Akitake: Bull. Jpn. Soc. Sci. Fish. 41, 1271 (1975)

70) K. Kobayashi, H. Akitake, C. Matsuda \& S. Kimura: Bull. Jpn. Soc. Sci. Fish. 41, 1277 (1975)

71) K. Kobayashi, S. Kimura \& E. Shimizu: Bull. Jpn. Soc. Sci. Fish. 43, 601 (1977)

72) K. Kobayashi \& N. Nakamura: Bull. Jpn. Soc. Sci. Fish. 45, 1001 (1979)

73) K. Kobayashi \& N. Nakamura: Bull. Jpn. Soc. Sci. Fish. 45, 1185 (1979)

74) K. Kobayashi, H. Akitake \& T. Tomiyama: Bull. Jpn. Soc. Sci. Fish. 35, 1179 (1969)

75) T. Shimizu, Y. Hashimoto \& J. Fukami: J. Pesticide Sci. 3, 311 (1978)

76) M. Miyauchi, M. Kondo \& M. Takagi: Bull. Jpn. Soc. Sci. Fish. 47, 871 (1981)

77) K. Hori \& M. Nakaji: Bull. Kumamoto Agric. Exp. Stn. No. 9, 131 (1981)

78) N. Watanabe, N. Ishida, Y. Ishimaru, Y. Katayama \& S. Kitayama: J. Pesticide Sci. 6, 31 (1981)

79) T. Yamagishi, K. Akiyama, M. Morita, R. Takahashi \& H. Murakami: J. Environ. Sci. Health B13, 417 (1978)

80) T. Yamagishi, K. Akiyama, M. Morita, R. Takahashi \& H. Murakami: Bull. Environ. Contam. Toxicol. 23, 57 (1979)

81) T. Yamagishi \& K. Akiyama: Arch. Environ. Contam. Toxicol. 10, 627 (1981)

82) T. Miyazaki, K. Akiyama, S. Kaneko, S. Horii \& T. Yamagishi: Bull. Environ. Contam. Toxicol. 23, 631 (1979)

83) T. Miyazaki, K. Akiyama, S. Kaneko, S. Horii \& T. Yamagishi: Bull. Environ. Contam. Toxicol. 24, 1 (1980)

84) T. Miyazaki, S. Kaneko, S. Horii \& T. Yamagishi: Bull. Environ. Contam. Toxicol. 26, 577 (1981)

85) T. Yamagishi, T. Miyazaki, K. Akiyama, S. Kaneko \& S. Horii: J. Food Hyg. Soc. Jpn. 22,
270 (1981)

86) T. Yamagishi, T. Miyazaki, K. Akiyama, M. Morita, J. Nakayama, S. Horii \& S. Kaneko: Chemosphere 10, 1137 (1981)

87) H. Mikuriya \& K. Miyahara: Proc. Assoc. Plant. Prot. Kyushu No. 22, 163 (1970)

88) H. Mikuriya \& K. Miyahara: Proc. Assoc. Plant Prot. Kyushu No. 23, 106 (1977)

89) H. Mikuriya \& K. Miyahara: Proc. Assoc. Plant Prot. Kyushu No. 25, 79 (1979)

90) M. Kato \& S. Maru: Bull. Chiba Agric. Exp. Stn. No. 19, 127 (1978)

91) K. Kono, S. Harumoto \& N. Nakamura: Bull. Miyazaki Agric. Exp. Stn. No. 12, 1 (1978)

92) S. Yamaya \& Y. Mizuno: Bull. Akita Agric. Exp. Stn. No. 24, 29 (1980)

93) T. Omae, M. Uno, T. Okada, Y. Onji, I. Terada \& K. Tanigawa: J. Pesticide Sci. 6, 437 (1981)

94) T. Kodama \& S. Kuwatsuka: J. Pesticide Sci. 5, 531 (1980)

95) M. Nakaji \& K. Hori: Kyushu Agric. Res. No. 43, 104 (1981)

96) H. Kazano, M. Asakawa \& C. Tomizawa: Jpn. J. Appl. Entomol. Zool. 10, 108 (1975)

97) R. L. Metcalf, G. K. Sangha \& I. P. Kapoor: Environ. Sci. Tech. 5, 709 (1971)

98) C. Tomizawa \& H. Kazano: J. Environ. Sci. Health B14, 121 (1979)

99) A. R. Isensee: Int. J. Environ. Stud. 10, 35 (1976)

100) K. Ishizuka, M. Amano, H. Ishida \& K. Fukunaga: Abstracts from the 2nd Annual Meeting of Pesticide Sci. Soc. Jpn., p. 232, 1977

101) C. T. Chiou, V. H. Freed, D. W. Schmedding \& R. L. Kohnest: Environ. Sci. Tech. 11, 475 (1977)

102) J. Kanazawa \& C. Tomizawa: Arch. Environ. Contam. Toxicol. 7, 397 (1978)

103) J. Kanazawa: Bull. Environ. Contam. Toxicol. 20, 613 (1978)

104) M. Imanaka, K. Matsunaga, A. Shigeta \& T. Ishida: J. Pesticide Sci. 6, 413 (1981)

105) K. Sugiura, S. Sato, M. Goto \& Y. Kurihara: Chemosphere 1, 39 (1976)

106) S. Tsuge, H. Kazano \& C. Tomizawa: J. Pesticide Sci. 1, 307 (1976)

107) H. Kazano, M. Asakawa, C. Tomizawa \& S. Tsuge: Jpn. J. Appl. Entomol. Zool. 11, 263 (1976) 